\title{
Tracing Constitutional Changes in Slovakia between 2008-2016
}

\author{
TOMÁŠ L'ALÍK*
}

\begin{abstract}
The paper analyses the constitutional revision process in Slovakia taking into account recent constitutional changes that have occurred since the financial crisis of 2008. The first part describes the forms of constitutional amendment procedure in theory and practice. The second part is devoted to the substantive and detailed examination of direct amendments taking place from 2008 onwards equipped with political situation that influenced each revision. Interestingly, during the period of study, all amendments but one were adopted as a response to the crises but all of them were connected to the political questions of a given moment. The amendments are completely in the hands of politicians and have become a tool to "show off" with little attention on possible constitutional damage. The regime of constitutional change in Slovakia is an ample illustration of political constitutionalism in practice.
\end{abstract}

Keywords: constitutional change in Slovakia, conceptual and procedural framework of amendment procedure, political constitutionalism, constitutional politics

'Change is the constant in life.'

Heraclitus

\section{INTRODUCTION}

Change is a common and very natural element in everyday lives and Heraclitus stated that change is intertwined with life itself. It seems that change has been part of human existence since the beginning as it brings development and allows evolution and without change, there is stagnation and no progress. Constitutions, whether conceived as the highest positive legal norm of a given legal order (H. Kelsen) or social practice (Hart's Rule of Recognition), are no exception and subject to change.

Changes to and within constitutions are both necessary and inevitable. Changes are necessary as otherwise there is an inherent risk that social reality might escape from the realm of constitution. Consequently, a constitution might not be able to regulate reality with social practice and become a meaningless piece of paper. Changes are also inevitable as they help to reflect evolution, development of social practices and reality while entrench them into constitutional text. Change, thus, allows a balancing pace to be kept between the current state of affairs in a country and its highest legal norm. In this sense state and constitution might diffuse together. ${ }^{1}$

On the other hand, the basic function of any constitution is to secure tranquility and prevent the status quo from change. ${ }^{2}$ Constitutions bring stability and allow progress through a long-lasting settlement of powers (the principle of separation of powers) as well

* Associate professor, Comenius University in Bratislava, Faculty of Law, Department of Constitutional Law, tomas.lalik@flaw.uniba.sk. This paper was written by the support of VEGA project No. 1/0777/15 'Výzvy a perspektívy vývoja ústavného práva Slovenskej republiky v procese európskej integrácie a globalizácie.'

${ }^{1}$ For Carl Schmitt such state of affairs represents an absolute concept of constitution. See Schmitt (2008) 60.

2 Some authors even suggest that constitution serves as a substitution to civil war. See Zupančič (2008) 21 et seq. 
as a compromise of values and other major issues within a society mainly human rights protection. This stability is usually attained either after a possibly violent revolution or gradual evolution. ${ }^{3}$ Constitutions are the evidence of fighting the change and conserving the past (and present) as long as possible. In this sense, American constitutional tradition influences a perception that constitutions should not be adopted only for a couple of years, but rather decades if not centuries. ${ }^{4}$ Finally, written constitutions detest change what is further evidenced on provisions making possible changes to and within constitutions more difficult. Some constitutions even prohibit a formal change through unamendable provisions (eternal clauses). Drafters and other constitutional actors including scholars are well aware of these facts.

From this perspective, a change to status quo is a possible threat to social peace established by a constitution. The following tension arises as although constitutional changes are necessary and inevitable, the very concept of the constitution serves as a counter fact to such necessity as one of its main function is to prevent change. Therefore when analyzing constitutional changes, the tension between stability and certainty and possible change or evolution must be acknowledged and appreciated. In addition, another and perhaps deeper conflict within constitutional law arises between constitutionalism and democracy. Constitutionalism tries to tame and impose limits on democracy, through legal norms, principles and values found in constitution whilst democracy is willing to overcome these hurdles and to re-establish itself in a perpetual process of re-creation and renovation.

Despite these tensions, changes do still occur no matter how fiercely a constitution fights a change, imposing either almost unattainable supermajorities (e.g., Art. V of the U.S. Constitution), eternal clauses (e.g., Art. $79 \S 3$ of the German Basic Law), employing various constitutional players or other obstacles into play. This, of course, is not the end of the analyses. Relevant factors of a change involve both certain forms in which constitutional changes occur as well as intensity, degree, context and nature of such changes. ${ }^{5}$ While the former inquiry deals with questions such as which institution is (can be) empowered and according to which procedures to amend a constitution the latter puts emphasis on more substantive questions. So there exists at least formal and substantive level when discussing constitutional change.

Also every process of a constitutional change involves both politics and law. Not only does politics transform into a fundamental legal regulation of a nation but also law influences politics at the beginning of the whole process by giving incentives. At the same time, law lays down obstacles in bringing changes into life. In the following sections of the paper, the formal and substantive process of constitutional change will be described as well the legal and political dimensions of constitutional changes with regards to Slovakia. ${ }^{6}$

The first part is an introduction allowing a foreign reader to form a picture about the formal issues of the constitutional change process within the Slovak constitutional law in

${ }^{3}$ For a profound analyses of these two avenues of constitutional development see Möllers (2006) 171-75.

4 'A constitution, by contrast, is drafted with an eye to the future.' See Hunter v. Southam Inc., (1984) 2 S.C.R. 145 at 155. Some scholars argue that the longer of life-span of a constitution, the better. For this inquiry see Elkins, Ginsberg and Melton (2009).

5 E.g., Carlos Bernal distinguishes among seven different categories of constitutional change. See Bernal (2014) 493-95.

6 There are more than these issues of constitutional amendment procedure both in theory and in practice. However, some limitations are necessary given the scope of the paper. 
both theory and practice. Politics dominates the process with the leading role of political forces in the Slovak Parliament ('National Council'). The second part of the paper is devoted to more substantive analyses of constitutional changes that occurred between 2008-2016. This period was not accidentally chosen, but to show how this agenda has changed after the financial and security crisis that hit the EU and its member states, including Slovakia. The main point of interest will be to offer an in-depth analysis of amendments and a try to place them into a larger political and legal picture. The final part is a summary of the analysis.

\section{CONCEPTUAL AND PROCEDURAL FRAMEWORKS FOR CHANGING THE CONSTITUTION IN SLOVAKIA}

\section{Historical Background}

The Slovak Republic is a successor state after the peaceful dissolution of former CzechoSlovakia in 1993. The Slovak Constitution was adopted on September 1, 1992 and it has endorsed a constitutional tradition with a form and practice of constitutional amendment procedure that was prevalent in various state forms in Czechoslovakia from 1920 to 1992. According to this legal and cultural tradition, parliament is the sole institution empowered to adopt and change the constitution. The agenda of constitutional amendment is vested to the political institution and therefore politics played a key role. This legacy is also visible in the current theory and practice of constitutional change regime in Slovakia.

The first constitution that regulated the process of constitutional change was adopted in the aftermath of the First World War when the Czechoslovak state was first established. The Constitution (No. 121/1920 Coll. of Laws) gave power to both chambers of Parliament and for the amendment to become effective it required consent of $3 / 5$ majority of all MPs. Consequently, the Constitution from 9th May 1948, already securing some principles of Victorious February Communist Revolution, followed a similar model when only both chambers of parliament could legally amend the constitution providing $3 / 5$ of majority in each house. The Constitution of 1960 (No. 100/1960 Coll. of Laws), with fully implemented communists ideology, empowered the National Assembly to enact and revise the constitution by $3 / 5$ of its majority but also to perform constitutional review and thus could declare statute of the Slovak National Assembly and other by-laws unconstitutional (Art. 41). Article 111 of the Constitution provided that the Constitution could be amended only by constitutional statute and since then, constitutional scholarship and practice has developed the tradition that only a parliament can change a constitution by adopting a constitutional statute.

The structure of the state underwent a profound change in 1968 when the constitutional statute (No. 143/1968 Coll. of Laws) came into force. The process of constitutional change remained intact although Czechoslovakia had become a federation. Again, the newly established Federal Assembly gained the power for revision and enactment of a new constitution as well as constitutional statutes. The Article 41 determined that these legal norms had to be accepted by $3 / 5$ majority of all members in each house of the Federal Assembly composed of the Peoples' House and the Nations' House. In the latter, the representatives of Slovak and Czech Nations were sitting together in parity and in order for a constitutional amendment to take effect, the Constitution required acceptance of $3 / 5$ of all representatives of the Slovak Nation as well as 3/5 of all representatives of the Czech Nation.

It is clear from this brief historical analysis that constitutional tradition heavily favored parliament over any other institution as the primary forum for change and even adoption of 
the constitution upon a 3/5 MPs' majority. Therefore, it came as no surprise that constituent power, emerged in 1992 during the crisis of Czecho-Slovak Federation also incorporated such tradition into new constitution. As a result, Article 86 let. a) of the Constitution from 1992 stipulates that the National Assembly has the power to adopt a new constitution and constitutional statutes and also that the National Council is the sole constituent institution in the Slovak Republic (Art. 72). Parliament is the only forum to amend the Constitution.

\section{The Formal Process of Amendments of the Constitution}

The process of formal constitutional amendment is done through constitutional statutes. Constitutional practice linked to the Czechoslovak tradition has emerged so that only constitutional statutes can de facto change constitution. ${ }^{7}$ De jure, constitutional text does not contain any derogation clause or explicit regulation of its own revision. The explicit standard of eventual review of constitutional laws mainly from a formal perspective is rather ruled out for this reason.

Few authors consider the absence of any derogation clause as the biggest threat for both formal and substantive level of constitutional change process. ${ }^{8}$ However, the Slovak Constitution contains different quorum for adoption of constitutional statutes (amendment) than ordinary statutes. Article $84 \S 4$ requires that constitutional statutes have to be accepted by at least 3/5 of all MPS (i.e. 90) in the National Council. ${ }^{9}$ As mentioned above, no other formal (and substantive) requirements are contained in the Constitution. Richard Albert classified such mechanism as legislative entrenchment and according to him, a law amending constitution must muster more than a simple majority in legislature and requires supermajority. ${ }^{10}$ This is the second lowest threshold on the scale of the five mapping constitutional amendment procedure organized from the least rigid (legislative nonentrenchment) to the highest (indefinite constitutional entrenchment). ${ }^{11}$ It is no wonder that some empirical analyses show that Slovak Constitution is considered to be the least rigid among written constitutions of the EU member states. ${ }^{12}$

From the formal point of view as well as considering Kelsenian pyramid of legal norms, it is necessary to note, that constitutional statutes and the Constitution itself enjoy the same legal force and rank within the Slovak constitutional system. ${ }^{13}$ Although this assumption causes discussions among scholars, ${ }^{14}$ in practice both norms are treated in the same way. This approach brings about several problems to the constitutional system.

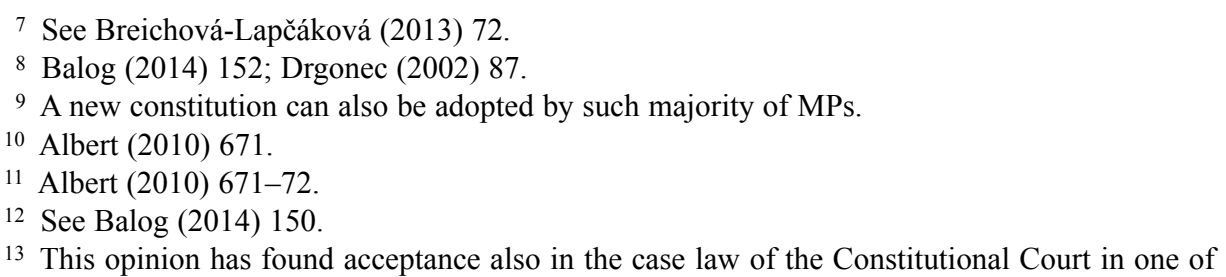
its first judgments; see in particular judgment I. ÚS 39/93 from June 21993 stating that between the Constitution and constitutional statutes is no difference in the legal force and thus they are not in vertical relation. Also Procházka (2011) 22.

14 Some argue that the Constitution takes precedence over a constitutional statute thanks to the Art. $152 \S 4$ stating that interpretation and application of constitutional statutes, statutes and other legal norms must be in conformity with the Constitution. See Drgonec (2012) 63-64; Orosz (2005) 326-30. Others deny this approach claiming that such interpretation is isolated and systematic interpretation of the provision - especially form of heading (transitory and final provisions) and its structure - does not allow such result. For the discussion see Herc (2009) 410-26. 
The main problem concerns constitutional statutes and their relationship toward the Constitution. There are at least three categories of constitutional statutes. ${ }^{15}$ The first category of such statutes explicitly and directly changes, derogates or supplements constitutional text. The second category of constitutional statutes are envisaged by the Constitution itself e.g., Article $3 \S 2$ provides that the borders of the state may be changed only by a constitutional statute. ${ }^{16}$ The third and the most problematic category of such statutes are those outside the Constitution. This category neither changes the text nor is envisaged by the constituent power in the Constitution. The problematic aspect rests on the assumption that such statutes have the same legal force as the Constitution. The National Council enjoys almost unfettered power, not only when and to what extent it can formally and substantially change the constitution in a direct manner, but also it can at any time change the constitution indirectly by adopting a constitutional statute beyond the Constitution itself.

Academia has been strongly critical of such an approach, arguing that the National Council is only a constituted institution and as such has to act only in a manner prescribed by the Constitution. And since the Constitution does not provide for unlimited power towards constitutional statutes, parliament cannot do so. ${ }^{17}$ At the same time, the Constitutional Court also directly prohibited the National Council to adopt any constitutional statutes except those envisaged by the Constitution. ${ }^{18}$ However, the National Council has decided to act otherwise and currently there are at least 15 constitutional statutes beyond the Constitution. ${ }^{19}$ This approach taken by the National Council is continuously subject to heavy critique in legal doctrine and some authors express their fear that parliament is abusing its position vis-à-vis other constituted institutions and constitutional values ${ }^{20}$ or that constitutional change is by such practice degraded only to a form lacking any substantive or axiological analyses. ${ }^{21}$

The problem of eventual unconstitutional amendments is further exaggerated by the fact that there is no legal basis for constitutional review of any amendment. Article 125 of the Constitution anchors that the Constitutional Court is entitled to perform judicial review only at the level of statutes. Explicit authority to review constitutional statutes is missing in

15 Some authors suggest that there are as many as five categories of constitutional statutes within Slovak constitutional order. See Breichová-Lapčáková (2013) 74.

16 Similarly, article $7 \S 1$, article $51 \S 2$, article $99 \S 1$ and article $102 \S 3$ of the Constitution.

17 E.g. Prusák (2005) 133-44; Bröstl (2008) 11 et seq.; Balog (2007) 1577-82; BreichováLapčáková (2011) 190.

18 See PL. ÚS 16/95 from 24 May 1995.

19 As a counterargument to this approach serves logical argument a majori ad minus i.e., when parliament can adopt new constitution it can adopt any constitutional law that deems necessary. This way of thinking was exposed in Procházka (2011) 41-42. For a critique see Lalík (2015) 90-92.

20 Breichová-Lapčáková (2013) 122.

21 Balog (2014) 170. Analysis provided by Carl Schmitt resting on exclusively formal characteristic of a constitutional concept rings true also for constitutional change process in Slovakia. Firstly, the constitution (as unity) and constitutional law (as detail) are tacitly rendered equivalent and confused with one another. Secondly, constitution in the formal sense and constitutional laws in formal sense are not distinguished. Finally, constitution and constitutional law mingles together, although they are drawn from entirely disparate perspectives; Schmitt (2008) 68. 
the text. ${ }^{22}$ However, silence on such power is not crucial from a comparative law perspective and courts abroad have not interpreted it as a negation of that authority. ${ }^{23}$

As a matter of such practice, the constitutional order of Slovakia is polylegal as outside of constitutional text, there are several constitutional statutes that also regulate constitutional content. The biggest threats of polylegality of the constitutional order are: the erosion of compatibility and stability of the Constitution; the tendency to add exceptions to the constitutional text outside the text itself and consequently emptying the content of the Constitution. Carl Schmitt warned against such a formal or rather formalistic approach claiming that an otherwise unified constitution perceived as the fundamental act of the constituent power may be dissolved into a series of individual constitutional laws. ${ }^{24}$

Despite the constitutional text being silent as for other avenues of formal constitutional amendment process, there exists another avenue which came into existence due to the caselaw of the Constitutional Court: a referendum. This mechanism is very limited due to the many factors that diminishes its real importance but nevertheless it is another mean for changing the Constitution.

In 1997, the National Council was unable to vote in the President of the Republic. A popular initiative supported by many politicians initiated a referendum changing constitutional rules about presidential elections in favor of a general election of the head of state. The Constitutional Court came into play as a group of MPs claimed that the President must not declare a referendum on changing the Constitution and they argued that the Constitution cannot be amended in a referendum.

In the decision PL. ÚS 31/97 from 21 May 1997, the Constitutional Court arrived at a conclusion that the Constitution can be amended by a referendum. The Court first emphasized the role of citizens as the original holders of power and fact that every constituted power is subject to administration of the people. Even parliament exercises delegated power. People themselves have nowhere in the Constitution renounced the power to amend the Constitution although they are also bound by the Art. $93 \S 3$ that exemplifies what cannot be subject of referendum - fundamental rights and freedoms, ${ }^{25}$ taxes, levies and state budget. The Court then analyzed the institute of referendum whose purpose is to secure the people concurrence in the exercise of state power. Referendums unlike plebiscites or popular initiatives have legal effects and must not be ignored by the state institutions. Several problems arise with this approach.

${ }^{22}$ Some scholars find such power in general provision of Art. 124 stating that: 'The Constitutional Court of the Slovak Republic is an independent judicial body charged with the protection of constitutionality.' See Balog (2014) 175-77; Drgonec (2015) 1320-27; Lalík (2015) 92-97. Others refuse such interpretation claiming that it violates formal aspect of rule of law (principle of legality) providing that any power of the State institution has to have legal basis, otherwise it acts ultra vires. For this approach see Procházka (2011) 39; Lipšic (1997) 30.

${ }^{23}$ For a comparative analyses of various jurisdictions see Barak (2011) 332.

24 For theoretical, normative, logical and other analysis of distinctions between a constitution and constitutional laws see Schmitt (2008) 67-88.

${ }^{25}$ Regarding fundamental rights and freedoms, the Constitutional Court adopted rather generous approach when referendum involves human rights questions. In recent decision PL. ÚS 24/2014 from 28 October 2014 it found that referendum may take place when standard of protection is increased or confirmed. So only if standard of human rights protection will be decreased, referendum must not be held. For an analyses see Zelenajová (2015) 160-66. 
The first and main problem stemming from such approach is rather theoretical and concerns the wording of the Art. $98 \S 2$ of the Constitution. It requires that all proposals adopted in referendums must be promulgated by the National Council in the same way as it promulgates laws. The Constitutional Court interpreted the binding effect of a referendum in a way that the National Council is obliged to secure legal effects of referendum. Parliament serves as an intermediary of the people, so even in a referendum, the people need a proxy in securing their will. This is a clear renunciation on the popular sovereignty when the delegated power is condition sine qua non for the delegating power in such extraordinary event. Ironically, the parliament provides a mouth for the holder of original power who remains speechless even though it had just talked. Taking the argument further, the constitutional mechanism in the Art. $98 \S 2$ effectively blurs the will of the people and their representatives. The whole idea of a referendum as a separate avenue or concurrent exercise of state power is lost and non-existent.

The second problem is represented by the concern of enforceability of proposals adopted in a referendum. According to the Art. $73 \S 2$ of the Constitution, MPs enjoy free mandate. Although it can be argued that the peoples' will prevails in a conflict between the will of the people and the will of their MPs ${ }^{26}$ the Constitution does not prescribe any sanctions nor limits for MPs not respecting the will of the people. Put differently, there is no mechanism of how MPs could be forced to implement proposals from a referendum. And this mechanism cannot be created by the Constitutional Court itself. ${ }^{27}$ Perhaps it is not ultimately correct to assume such divergence regularly may occur due to political consequences in ever-approaching elections, still such a scenario remains a hypothetical possibility that decreases the importance of referendums in the constitutional system.

The third issue refers to a question of the direct effect of proposals adopted in referendums. The problem lies in the formal aspect and nature of a question put forward in a referendum. De lege lata questions in referendums must be formulated allowing a yes or no answer. Moreover, they must not be mutually conditioned. ${ }^{28}$ To attract voters questions are simplified to a meaningful and attractive form. According to the legal regulation, an explanation can be a part of the question if the question is complex.

Current Elections code as well as the former statute on the conduct of referendum have not addressed whether a wording of a constitutional amendment can be a part of ballot questions. Unfortunately, the Constitutional Court, in its judgment, negatively interpreted such possibility. However, it could have found otherwise and the legislative silence interpreted more generously towards the original holder of power. The wording of an amendment cannot be subject to a referendum directly. Now, in order for the referendum to regain its effect it is necessary to change the Elections Code and to permit the wording of an amendment as a part of ballot questions or the explanation. This does not seem a probability due to the missing political will. ${ }^{29}$ By then constitutional amendments cannot be included neither in the question nor in the explanation to a ballot question. Only a general question regarding an amendement the constitution can be put a referendum.

${ }^{26}$ As envisaged by Jean Jacques Rousseau (1947) 83.

27 A referendum about accession to the EU took place on May 17, 2003 to allow citizens to decide. Notwithstanding, it was the only valid referendum in the Slovak history (the turnout $52,15 \%$ of eligible voters with acceptance of 92,46\%), still $10 \mathrm{MPs}$ and representatives of the Communist Party voted against the approval of Treaty on joining the EU (print No. 261, voting No. 8).

$28 \S 202$ (3) of the Elections Code; Law No. 180/2014 Coll. of Laws.

29 On July 1, 2014 the Elections Code came into force replacing statue No. 564/1992 Coll. of Laws on the conduct of referendum but have not changed anything in this regard. 
The main issue remains with questions that bring fundamental or considerable changes into the legal system. As stated earlier, for obvious reasons, ballot questions are formulated in ordinary language and simple fashion - to be understood, to raise awareness and to grasp attention. Questions perceived to be easy may become a complex issue for implementation. An example could be the question 'Are you in favor of enacting a new constitution?' While some crucial features of a new constitution might be stated in order to explain this question, the full-fledged new constitution as a complete legal document cannot form a part of the explanation. It is therefore not clear what the new constitution will look like and what kind of consequences will flow from valid a referendum. The problem is two-fold. Firstly, this situation undermines certainty of both (i) people participating on referendum and expressing their will and (ii) MPs who even acting bona fide and ready to enforce the referendum with sincere concerns may not know what course of action to take in order to satisfy the will of their master. Secondly, complex questions requiring further in-depth actions by the National Council (and eventually other institutions) broaden discretion of MPs because a different course of action might be taken to implement the will of people. This also means less actual influence of the peoples' will in the final product and eventually a negation of their will.

However, not every question put forward in referendum raises similar concerns. For example a question 'Are you in favor of decreasing the number of MPs to 100?' does not cause similar difficulties although it is not without discretion on the part of MPs at least from a temporal perspective (whether to implement such will hic et nunc? or only for the next elections? etc.). Consequently, effectivity of a referendum depends not on the ballot questions but rather on the complexity of issues that stand behind them. The more complicated the issue, the more discretion and uncertainty on the part of the National Council and less influence on the part of the people. With particular questions, enforceability of a valid referendum might diminish to minimum. People cannot control the course of action taken after successful referendum while MPs might be unsure as well.

The result is that people speaking through referendum do not only need a proxy that is paradoxically created by them but oddly enough such proxy is a veto player in respect of their will. Even if the National Council is willing to accept the will of the people, it is still not clear how such will should be transformed into a legal world. The situation is exacerbated when questions require a detailed normative act or even the series of normative acts. Consequently, the legal effects of referendums oscillate somewhere between minimal and illusive. The same is true for the possibility of changing the Constitution in referendums. Consequently, the National Council remains the primary and the only forum for the constitutional amendment process.

To assess the amendment process as completely without any substantive limits would be a mistake. The Constitution in general provisions provides for some indirect substantive limitations on the power of the National Council to amend the Constitution. The first is found in the Article $12 \S 1$ that prohibits inter alia abolition of fundamental rights and freedoms. Wording of the article is unambiguous and precise and certainly establishes legal limits to the unfettered power of the National Council. Beside the Constitution itself, the Constitutional Court seems to develop its own understanding of the nature and intensity of the change.

\section{Judicial Review of Constitutional Amendments}

The Constitutional Court was confronted with serious violations of the principle of separation of powers shortly after independence and during the period of upheaval in the 1990s. These violations were caused by the process of privatization when various state 
entities and property in general were transferred onto private individuals and entities alike. In one of its seminal judgments, while declaring unconstitutional a statute that abrogated governmental regulations enabling the process of privatization and declared all contracts concluded upon therein as null and void, held that the Slovak Constitution contains principles that are free from change as they have constitutive meaning for Slovakia. At the same time, it added that the National Council is also bound by such principles (separation of powers in this case). ${ }^{30}$

However, the Court has never been confronted with an application directly challenging the constitutionality of a constitutional statute except of one rare case. There was no political will to form a new coalition following the break-down of Iveta Radičová's government initiated by a non-successful vote of confidence intertwined with voting in favor of European System of Financial Supervising in 2011. The formal procedure to dissolve the National Council is rather restrictive and thus the practice of adopting an $\mathrm{ad}$ hoc constitutional statute limiting the term of office of an incumbent parliament emerged. This case was no exception and in order to solve the political crises, constitutional law No. 330/2011 Coll. of Laws was adopted effectively suspending for this one occasion the otherwise generally applicable constitutional norm stating that MPs are elected for a period of 4 years. ${ }^{31}$

An applicant challenged such constitutional law claiming that it violates his subjective right to participate on the administration of public affairs and his legal certainty as he voted for candidates knowing that they are elected for 4 years period. He also relied on more general arguments that normative acts must not be individual and at the same time claimed that the constitutional statute is retroactive.

The Constitutional Court rejected the application on formal grounds. However, in its reasoning offered a standard that might give both hope and predict the future of how the Constitutional Court may handle similar applications challenging constitutional statutes. After commenting extensively on comparative constitutional law in regard to the constitutionality of constitutional laws, unusual fact when a complaint is rejected on formal grounds, it went on to apply the so-called Plaumann test as applicable by the ECJ. ${ }^{32}$ In the decision the Court assessed whether the applicant was (i) directly and (ii) individually affected by the act notwithstanding its declared form. For the ECJ, it is necessary that 'persons other than those to whom a decision is addressed may only claim to be individually concerned if that decision affects them by reason of certain attributes which are peculiar to them or by reason of circumstances in which they are differentiated from all other persons and by virtue of these factors distinguishes them individually just as in the case of the person addressed. ${ }^{33}$ The Slovak Constitutional Court applied the test and concluded that the applicant's position was very far away from being directly and individually affected by the constitutional law in question in order to permit any such considerations. ${ }^{34}$ However, the test might serve as the eventual future standard of review of constitutional laws.

30 See judgment PL. ÚS 16/95, 24 May 1995.

31 It remains a secret why $3 / 5$ of the majority in parliament when deems rules set out in the constitution as too rigid-to-get-along do not change them and rather adopts individual constitutional statutes.

32 Such test was suggested by Procházka (2011) 43-47.

33 See Case 25/62 Plaumann \& Co v Commission [1963] ECR 95.

34 See decision II. ÚS 153/2013 from 28 February 2013. 
It is quite clear that when such a standard is to be employed, it will only be in cases of constitutional laws that both directly and individually affects a person. Consequently, such protection will be rather given at the level of subjective constitutional law with the human rights at its peak. On the contrary, objective constitutional law represented by the principle of separation of power will most likely be omitted from the protection by such standard. It remains to be seen if such standards will ever become applicable taking into account the rather passive attitude of the Court towards political branches of the government. After this brief introduction, attention now switches to recent constitutional amendments that occurred since 2008 .

\section{CONSTITUTIONAL CHANGES IN SLOVAKIA (2008-2016)}

The biggest financial and economic crisis of current times started in the second half of 2007 and reached its peak in 2008. Several banks and private financial institutions either collapsed or went into insolvency. The whole banking systems of many countries broke down e.g., Ireland, Portugal, and Greece and the situation required interventions from governments with the strong support on the part of the EU institutions (mainly the ECB) and other international organizations (World Bank, International Monetary Fund). Eventually, they succeeded in saving banks and countries from complete collapse at the costs of higher unemployment, cuts in social benefits and increasing national debts. Implications of the crisis are still to be felt for decades to come. Naturally, Slovakia was also hit by these events.

The first effects of the crisis started to influence the Slovak economy in late 2008. National economy had begun to stagnate after many successful years when the GDP had been gradually rising in decent numbers. Domestic economic activity decreased and the industrial sector, heavily dependent on exports, significantly declined by 15 percent. These facts led to higher unemployment and less security among employed persons. In the two following years (2009-2010) unemployment reached 14 percent. It took another three years for the economy to partially recover, when national GDP and employment returned to their pre-crisis values.

The government responded by various means in order to fight the negative effects of the crisis. In late 2008, the cabinet adopted 27 and 38 different measures respectively affirmed by the National Council. They focused on various policies including monetary, fiscal, budgetary, employment, taxes and levies, pricing and salaries, aimed at improving employment rates, helping to stimulate the national economy and providing a safety net for those who found themselves jobless. However, these actions occurred only at the statutory level while the Constitution itself remained untouched.

In respect of the financial crisis, the National Council adopted important constitutional statute standing beyond the Constitution under the No. 493/2011 Coll. of Laws on budgetary responsibility (8 December 2011). This statute sets forth many significant mechanisms when the deficit of the national debt would reach above 40 percent and lower than 50 percent of national GDP. However, the full scale effect of these mechanisms can be used only from 2028 and until then, a long transitory period with the less strict figures remains in force. The statute also created the Board for Budgetary Responsibility as an independent institution for monitoring and evaluating economic development and rules for budgetary responsibility.

At the later stage of a given period, security issues has come to spotlight due to various terrorist attacks in different European cities, most notably the tragic events in Paris. This fact led to the adoption of the last constitutional amendment in the analyses covered below. 


\section{Confiscation of illegally obtained property}

During the implications of crisis, the life of the Constitution sensu stricto remained intact. The first direct constitutional change after the crisis took place in 2010 and had nothing to do directly with the crisis. Rather, it demonstrates a typical example of the nature, degree and context of constitutional amendments. The National Council passed a constitutional statute No. 100/2010 Coll. of Laws adding another provision to Art. 20 that guarantees right to property: 'Other encroachments on the right to property are allowed only in regards of unlawfully obtained property or illegal income and such measures are necessary in a democratic society for national security, protection of public order, morals or the rights and freedoms of others. A statute enacts conditions.'

This constitutional change represents attempts lasting several years by different governments to penalize people who obtained their property in illegal way or their standard of living does not correspond to their 'officially' obtained wealth. What needs to be emphasized, this expropriation is to be conducted outside the criminal law. To put events in larger picture, the national economy underwent a profound revolution in the $90 \mathrm{~s}$ after gaining independence, during which state enterprises were bought by the newly established companies. Politics, of course, played a major role and many of the states' enterprises built by generations of Slovaks were turned over to private hands overnight or left deliberately go bankrupt. New owners were directly or indirectly connected to political elites of that time and these people earned fortunes. Also mafia-style people, who in communist times almost did not exist, emerged controlling various industries and earning incredible sums of money.

Initial efforts to legally confiscate illegally obtained property outside criminal law guarantees began in the early 2000s and were finalized by the statute No. 335/2004 Coll. of Laws on proving origin of property. However, the response from government was clearly disproportional to the pursued aim. Numerous 'pearls' appeared among the statutes' various provisions such as presumption of guilt, the obligation of an accused person to cooperate with an on-going investigation, forfeiture of property when a person was unable to demonstrate the origin of a property and full retroactivity of the statute. It was no wonder that such statute as a whole was declared unconstitutional by the Constitutional Court in its judgment PL. ÚS 29/05 (September 3, 2008) as it violated many principles of rule of law as well as the right to property. However, such a judgment did not discourage the Slovak political elites in their search for a constitutional solution.

The current version of constitutional statute served two aims. Firstly, it should revive political and general discussion aiming at popularity gain before incoming elections that took place later in 2010. The purpose was to demonstrate to voters how politicians see and care about the problem. The second aim was declared in the explanatory statement of the statute. In particular, the amendment is the framework of a legal basis for another statute that will enable the confiscation of illegally obtained property. The latter was accomplished by the statute No. 101/2010 Coll. of Laws that is again very constitutionally dubious because it stipulates excessive powers of the Financial Police, obligation of an accused to cooperate with the prosecutor, loss of property as a sanction, full retroactivity and presumption of guilt (if one cannot prove origin of property, the property forfeits). ${ }^{35}$ To the

${ }^{35}$ It is necessary to note, that regardless of legal qualification of statute, criminal law guarantees are applicable because of the nature of imposed sanctions. Loss of property is clearly a criminal sanction in substantive sense in the case-law of the ECtHR; for the approach of the ECtHR see e.g. Milenković v Serbia App. No. 50124/13 (ECtHR 1 March 2016) § 33 and cited case-law. 
best of all knowledge, the statute has never been used and the first aim was not also reached as the ruling coalition lost general elections in 2010 .

Such changes brought about by the constitutional statute has been meaningless from the legal points of view as well. Firstly, one of the general principles of law is that illegal acts do not enjoy protection. Secondly, the strict test of proportionality introduced by the statute is applicable always when personal and political rights are at stake regardless of its explicit formulation. Applicability of the test in the Slovak context flow from Art. 13 of the Constitution and at the same time from supranational law including practice of supranational courts.

Nevertheless, the topic of confiscation of unlawfully obtained property is far from over. Even today, it continues to be a hot issue in the politics and a political ever-green. ${ }^{36}$ Therefore every political party wishing to enter the National Council at least tacitly supports similar regulations. ${ }^{37}$ Law on confiscation of unlawfully obtained property is a must when you plan to seriously run in parliamentary elections. So another legislative attempt on statutory or even at the constitutional level is expected to arrive sooner or later.

\section{Heading towards neopresidentialism?}

The following constitutional change occurred during the political crisis after the down-fall of Iveta Radičová's government following the parliamentary vote of no-confidence in 2011. There was no chance to form a new government due to the allocation of political forces in the parliament. To solve the crises, political elites adopted an ad-hoc constitutional statute for premature general elections (No. 330/2011 Coll. of Laws). However, the question of what to do with the incumbent government until the new one would be formed remained to be determined. The Constitution in the Article $115 \S 1$ provides that the president recalls the government if the National Council passes a vote of no-confidence, or if the parliament turns down the government's request to pass a vote of confidence. Para 2 of the same article states that if the president accepts the government's resignation, he will entrust it with the execution of its duties until a new government is appointed.

Political leaders as well as the president were of the opinion that these provisions do not allow the president to entrust the government with its powers in a case that the parliament passed a vote of no-confidence and when the president recalls the government. The main reason was that the Constitution was silent on this point, lacked explicit guidelines and the state institutions can act only when they have such explicit power. ${ }^{38}$ Such a situation could be overcome by either (i) using analogia legis to interpret Art. $115 \S 2$ as to also include the situation when the parliament expresses no confidence in the government taking into account that both forms of government's termination of office (no confidence and resignation) are substantially equal or (ii) using systematic interpretation of Art. $115 \S 2$ in a way as to include the situation described in $\S 1$ of the same article. However, political

36 See the recent statement of one of the current opposition leaders Igor Matovič, who stated in a regional newspaper towards current coalition leaders: 'A day will come when we confiscate stolen property from you and from the people you hide.' For a complete summary of his statements towards confiscation see Pravda daily (2016) ) <http://spravy.pravda.sk/domace/clanok/391254-politickevyhrazky-na-lahku-vahu/ > accessed on 25 May 2016.

37 See last bill proposed by parliamentary political party OLaNO that was turned down in the National Council on May 24. 2016, print No. 79.

38 See also explanatory statement of the constitutional law No. 356/2011 Coll. of Laws. 
elites chose otherwise and decided to add a new provision in the form of constitutional amendment No. 356/2011 Coll. of Laws. The content of the amendment will now be briefly discussed.

Such provision creates a unique mechanism of state of affairs between the president and the government in the Slovak constitutional system in respect of three categories of governmental powers. After a vote of no-confidence in the parliament, the president recalls government and entrusts it with only certain powers that are exhaustively specified in new provisions until the new government is formed. Realization of some other explicitly stated powers is dependent on prior consent of the president in every single case. A third category of governmental powers simply cannot be realized at all.

Such regulation would not be a surprise if Slovakia was not a parliamentary republic with only a symbolic head of state with limited accountability and counter-signature of his many acts by the government. The president who needs for his many acts countersignatures by the government is now in the position that his signature is the condition for governmental action. The amendment strengthens the position of president $v i s$ - $a$-vis the role of parliament whose role has been decreased in that the recalled government is rather accountable to the president than to the parliament. The amendment introduced a feature of neo-presidentialism into Slovak constitutional order because the president now controls to some extent actions of the government.

It is hard not to notice many flaws inherent in this amendment. The first is the question of accountability. Who is responsible for acts of the government after the counter-signature by president? It is certainly not the government, but the accountability of the president is also very limited. ${ }^{39}$ Secondly, the government is quite limited in its actions and some actions cannot perform at all. What would happen when the government entrusted by the president had to act in this way few months or even years? Thirdly, it is not clear what to do when the government has to act as one of the substitutes for the president when his office is vacant or the president is unable to perform his duties. Fourthly, what is the status of individual members of government? Can they be recalled? One can get an expression that this amendment has brought more problems and questions than it had resolved. ${ }^{40}$ No surprise when you learn that this provision was prepared in record time: four hours.

\section{The Abolishment of Criminal Immunity of MPs and Judges of the Constitutional Court}

Another constitutional change marked the 20th anniversary of the enactment of Constitution. The amendment No. 232/2012 Coll. of Laws abolished obligatory consent of the National Council with criminal prosecution of MPs and also mandatory consent with criminal proceeding of constitutional court judges by the Constitutional Court. Its ultimate aim was to create equality between MPs, Constitutional Court judges and citizens. The amendment resulted in MPs losing their privileged position in terms of criminal prosecution and consent of the National Council is no longer required.

To put events in broader perspective, the privileges of MPs in respect of criminal and other prosecution had been gradually weakened since 2000s. Initially, MPs enjoyed a very

39 They can be only recalled by the ruling of the Constitutional Court for intentionally violating constitution or for high treason when $3 / 5$ of MPs fill the claim. The second possibility represents popular referendum initiated by the proposal of the $3 / 5$ of MPs.

40 For a detailed analyses of the amendment see Giba (2013) 169-75; Balog, Svák (2012) 23-40. 
wide criminal immunity with Article $78 \S 2$ of the Constitution provided that they could not be criminally or disciplinary prosecuted nor taken into pre-trial detention without the consent of the National Council. If such consent was not given, prosecution was barred forever. This provision was subject to change by constitutional amendment No. 90/2001 Coll. of Laws that abolished the provision barring prosecution forever and inserted only temporal obstacle providing that an MP cannot be prosecuted in case of no-consent when holding the office. Time-limits for such period did not apply. This amendment also introduced civil liability of MPs for their statements in the National Council as well as in its organs. However, this civil liability was later abolished by the constitutional amendment No. 140/2004 Coll. of Laws in order to (i) prevent MPs from being sued by political adversaries and (ii) to allow freer discussion in parliament. ${ }^{41}$ Later on, the constitutional law No. 210/2006 Coll. of Laws abolished immunity in respect of administrative sanctions followed by the constitutional statute No. 232/2012 Coll. of Laws.

However, it is still not possible to talk about full equality between citizens and MPs because the latter kept two procedural guarantees in comparison to the former. Firstly, their pre-trial detention is contingent on the consent of the National Council (Art. $78 \S 3$ ) and their apprehension and arrest is conditioned upon the consent of the Mandate and Immunity Committee of the National Council (Art. $78 \S 4$ ). If these consents are not given, pre-trial detention or apprehension must not be imposed against an MP. In my opinion, such regulation represents a sound compromise between full immunity and accountability of MPs on the one hand and certain guarantees of MPs against encroachments and perhaps even a misuse of authority in the executive power on the other. Slovakia is far from being a stable democracy with proper political culture. Political opponents from either side of the political spectrum can easily become primary targets and subject to criminal investigation. ${ }^{42}$ Politically motivated criminal prosecution, unfortunately, cannot be completely ruled out.

Constitutional statute No. 232/2012 Coll. of Laws had also affected the status of the Constitutional Courts' judges. According to the constitutional text, the judges enjoy the same immunity and procedural guarantees as MPs so effectively they have become fully accountable in criminal law except their decisional powers. However, similar to MPs, taking a judge into pre-trial detention requires the consent from the Constitutional Court (Art. $136 \S 2$ in fine). Otherwise, judges of the court do not enjoy any special treatment in regards of criminal prosecution.

\section{Definition of Marriage and Enhancing Judicial Accountability}

Perhaps the most extensive constitutional amendment in the period was constitutional statute No. 161/2014 Coll. of Laws. It had touched different parts of the Constitution but its main focus was judicial power. The formal argument for the National Council's intervention

${ }^{41}$ See explanatory statement to the constitutional statute No. 140/2004 Coll. of Laws; print No. 517.

${ }^{42}$ See a press conference during election campaign in February 2016 where the Prime Minister Robert Fico publicly accused and showed evidence against the prominent opposition figure Igor Matovič that the committed tax frauds in his former company in amount of 4 million euro. Investigation into suspicious activities of Mr. Matovič started immediately; Aktuality (2016) <http:// www.aktuality.sk/clanok/313185/fico-obvinil-matovica-vraj-prepral-122-milionov-cez-bielehokona/> accessed 27 May 2016. 
was low public confidence in the judiciary ${ }^{43}$ and attempts to increase judicial accountability. The constitutional reform drew on many various aspects. Timing was also decisive as the amendment took place before the presidential elections where one of the candidates was also the incumbent Prime Minister Robert Fico.

Firstly, it abolished the immunity of judges of general courts, as their criminal prosecution required the consent of the Constitutional Court. Such privilege has been abandoned by the amendment but judges still cannot be held criminally liable for their decision even after the termination of their function (Art. $148 \S 4$ ). However, judges cannot be taken into pre-trial detention without the consent of the Constitutional Court (Art. $136 \S 3)$.

Secondly, the powers of the Judicial Council were extended for the purpose of its increased role or administration of justice. The Judicial Council acquired authority to issue an Ethical Code for the judiciary with the cooperation of justice councils. ${ }^{44}$ The existence of ethical principles beyond judges' legal obligations and their stricter liability for not respecting these principles should increase public confidence among the population.

Further on, the former single function of the President of the Supreme Court and the President of Judicial Council were separated. This change was made in order to remove the judge Štefan Harabin who for several years held various high positions in the judiciary including the presidency at the Supreme Court and in the Judicial Council. For many, he represented the judiciary itself. Unfortunately, he is known for many incidents such as libel lawsuits against various media, degrading and removing opponents within the judiciary through disciplinary proceedings to other courts or different judicial offices at a court. Many perceived him as allegory to justice and the main reason for a lack of public confidence in the judiciary. Although I think that Mr. Harabin has his share in the current state of judiciary, he is not the reason for the state, but rather its consequence. The problems of the judiciary are much deeper and structural - a decorative change at the head does not solve the problem. This is also confirmed by the fact that the judiciary has been run by different people for two years but no positive changes were achieved yet and nothing suggests that anything is in sight.

The President of the Judicial Council is now one of the highest state officials in terms of material benefits unlike the rest of Judicial Council members who hold only honorary offices in the council. The President of the Judicial Council also gained a power to initiate a proceeding before the Constitutional Court in regards of constitutionality of statutes when they affect the judiciary. ${ }^{45}$

The amendment introduced a new condition for the future judges as well as the incumbent ones. All judges must now fulfil 'preconditions of judicial abilities' (predpoklady sudcovskej spôsobilosti). The preconditions in general should help to assess judges and candidates from ethical, personal and social points of view. In practice, information includes

43 According to the latest published polls by the NGO Via Iuris in October 2015 as many as $74 \%$ of the population does not have confidence in judiciary; Via Iuris $(2016)<$ http://www.viaiuris. sk/aktualne/568-dovera-voci-sudom-opat-kl.html > accessed 28 May, 2016.Unfortunately, this is a general trend in the society towards all public institutions excluding the President.

44 Justice councils unlike the Judicial Council are autonomous entities created by judges themselves in every court.

45 She already availed herself of such authority and successfully challenged the statute freezing salaries of judges for the year 2015. The Constitutional Court declared the law in respect of judges as unconstitutional in the judgment PL. ÚS 27/2015 from 25 November 2015. 
the private and family life of a person, prior work experience and social contacts. It is thought that preconditions should serve as the means to increase public confidence of judiciary.

During the process of appointment, preconditions are assessed by the Judicial Council on the basis of information provided by the secret service and intelligence and also information given by a candidate. If a candidate does not fulfil the criteria, she will not become a judge. This condition for holding a function has retroactive effect as even incumbent judges have become subjects of investigation by the Judicial Council and secret services. When a judge stops conforming to criteria, disciplinary proceeding are instigated against her ending up in dismissal from the office. Judges and candidates can lodge an appeal against negative decisions of the Judicial Council on the Constitutional Court whose decision is final.

Given such exceeding encroachment especially by the executive power on judicial functions, no wonder that outrage among judges and other elites followed. It was the President of the Judicial Council that challenged respective statutes that execute constitutional amendment in respect of incumbent judges arguing that regulation is retroactive, violates the separation of powers principle, the independence of judiciary and legal certainty. The Constitutional Court accepted her application on 17 September 2014 in the decision PL. ÚS 21/2014 and until decision on the merits it suspended effects of challenged provisions. To this day, a decision on merits has not been adopted, thus remains to be seen how the Court will assess the regulation. What is certain and of particular interest, the Court in the judgment will have to deal also with the constitutional statute No. 141/2014 Coll. of Laws itself because the challenged statutes only execute constitutional provisions and the Constitution and statutes are substantially intertwined. The question of constitutionality of constitutional amendments and their judicial review could be possibly opened and revisited.

The constitutional amendment also touched the position of the Constitutional Court. It violated finality of its judgments by introduction of a new provision that allows to submit an extraordinary remedy against its decision. The provision refers to reopening of a trial after a decision of an international organ of an international treaty by which Slovakia is bound gave rise to the obligation to revise a decision of the Constitutional Court (The Art. 133 of the Constitution). This provision was the reaction on impossibility to re-open a procedure before the Constitutional Court after judgments of the ECtHR found a violation of the Article 6 of the ECHR. An individual case is behind the provision.

Mr. Harabin, as mentioned previously, has been controversial figure in the Slovak judiciary. In 2011, the Ministry of Justice decided to investigate his various cases as the President of the Supreme Court (e.g. handling with files, not allowing an audit at the Supreme Court etc.) and launched disciplinary proceedings. Under the Constitution, the sole institution for conducting such proceeding is the Constitutional Court. In its decision PL. ÚS 92/2011 it found that Mr. Harabin is guilty of some disciplinary wrongdoings. Mr. Harabin lodged an application to the ECtHR claiming various violations of his procedural rights before the Court under Article $6 \S 1$ of the ECHR, namely that the bench of the Court was not impartial. ECtHR found violation of Art. $6 \S 1$ of the ECHR in that very respect and stated: "The most appropriate form of redress in cases like the present one would be the reopening of the proceedings, if requested, by a tribunal complying with the requirement of impartiality within the meaning of Article 6."46 However, the legal order did not allow

46 Harabin v Slovakia App. No. 58688/11 (ECtHR, 20 November 2012) § 178. 
explicitly for reopening a procedure before the Constitutional Court. Although Mr. Harabin sought such reopening, the Constitutional Court refused to do so on 29 October 2013 by the decision PL. ÚS 6/2013. The Court split but was unable to adopt any decision because the Constitution in Art. $132 \S 1$ in fine requires that for the decision on merits in plenary issues the Court must adopt a decision by minimum 7 votes (out of 13), otherwise application is rejected. ${ }^{47}$

This fact was a huge incentive for a delegated constituent power to pass an amendment overcoming such an impasse and to enable the reopening of a procedure before the Constitutional Court in future cases when violation of the Convention was found. Details of the constitutional amendment are formulated in $\S 75$ of the Constitutional Court Act No. 38/1993 Coll. of Laws. So far the Court has adopted a practice that firstly it decides about the formal conditions of an application for the reopening procedure and only later renders a decision whether to allow a trial de novo. ${ }^{48}$ The case record is not long enough to discern far-reaching conclusions but for now it seems that the Constitutional Court adopted a generous approach towards interpretation of the obligation stemming from a decision of the ECtHR. Even if the ECtHR does not explicitly indicate that the re-opening would be the best remedy for an applicant, the Constitutional Court prefers substantive protection of applicants' rights and enables re-opening also in such cases. ${ }^{49}$ However, the Court was not so generous towards Mr. Harabin and his new application after the constitutional amendment while rejected found that it already substantially analyzed his case in a prior decision (PL. ÚS 6/2013). This decision is res iudicata. ${ }^{50}$

Last but not the least, part of the constitutional statute No. 161/2014 Coll. of Laws dealt with the definition of marriage. The amendment set forth a new wording of the Art. $41 \S 1$ that the marriage is a unique union between a man and a woman. This case also illustrates how constitutional changes come into being by a way of political compromise.

The dominant political party of that period SMER-SD, which alone could create a government after a premature general election in 2012, had a clear majority of 83 MPs in the National Council. Before the presidential elections in which the prime minister ran, the SMER-SD decided to reform the judiciary as it had become less popular by introducing more accountability and also to revoke Mr. Harabin from his functions. In order to do that, it had to pass a constitutional amendment. As stated earlier, for passing a constitutional law the consent of 90 MPs is required, so at least 7 MPs had to be obtained from other political parties forming the opposition. The negotiations had started and within a few weeks conservative Christian democrats (KDH having $16 \mathrm{MPs}$ ) were on board to join the bill.

47 Some judges stuck to a formalistic reading of the Constitution that explicitly did not allow a re-opening of the procedure and stated that decisions of the Court are final. Unlike Spanish Constitutional Court who in decision Barbera (No. 245/91) in similar circumstances did allow for the reopening of procedure after violation of the Art. 6 of the Convention in respect of a criminal proceeding conducted before courts of general jurisdiction. Spanish legal order was silent on this point and the court extensively interpreted Art $10 \S 2$ of the Spanish Constitution to arrive at such result. See Hartwig (2005) 882.

48 See decision PL. ÚS 1/2016 from 19 January 2016, § 17.

49 E.g. decision III. ÚS 650/2016 from 24 February 2016, § 11; decision III. ÚS 347/2015 from 27 October 2015.

50 See decision PL. ÚS 1/2016 from 19 January 2016, §§ 19-21. 
Of course, their condition for the support was the precise definition of marriage that landed on the same constitutional amendment as the reform of judiciary. Political constitutionalism in full swing and evidence of how two rather unrelated issues can end up together.

\section{Prohibition on Water Export}

The following unique constitutional statute was passed on 21 October 2014 under No. $306 / 2014$ and unlike previously discussed issues, it dealt with ecology, environment and protection of the water resources in Slovakia. This amendment has supplemented the Constitution in two important ways. Firstly, it added a provision of declaratory nature to the Art. 4 stating that the Slovak republic protects and enriches its natural heritage and the country makes use of it effectively and gently in the benefit of the Slovak citizens and future generations. It has also created rather limited regime of doing business with water coming from Slovakia. Especially, the latter is of a particular interest.

In general, Slovakia has very large water resources. ${ }^{51}$ The government has finally decided to protect them on the constitutional level by inserting the provision that it is forbidden to transport water taken from water resources in Slovakia abroad by means of transportation or pipelines. This ban however does not include water for personal consumption, drinking water and natural mineral water packed to consumers' packages within Slovakia and to provide water for humanitarian aid and in a state of emergency. ${ }^{52}$

This constitutional amendment had two purposes. At the constitutional level it executed the decision of the government No. 583 from 24 October 2012 aimed at more intense protection of water, to define water as a strategic natural resource and national interest, to regulate the transport of water abroad including water that is found on territories of two or more states and to determine a fee for license allowing transport of underground water abroad..$^{53}$ It also prevented a Polish company in its effort to put into operation a pipeline from the Slovak village Legnava to Poland in order to transport water from Slovakia to Poland and sell it on the Polish market.

The reaction from the Polish company that had already invested a considerable sum of money into the pipeline and its business plan was quick. It decided to sue Slovakia on the basis of a bilateral treaty between Slovakia and Poland on the protection of investments for introducing such ban on water export claiming a loss of interest and violation of legitimate expectations. On the top of that, Slovakia has been subject of the investigation by the European Commission in the infringement procedure under the Article 258 of the TFEU. The fate of the provision that bans transport of water is unclear especially in respect of the EU law. Although Article $7 \S 2$ of the Constitution states that EU law takes precedence over statutory law only, the Constitutional Court in its decision PL. ÚS 3/09 implicitly declared priority of EU law even over the Constitution. ${ }^{54}$ So if the provision violates EU law its abolition might seem necessary.

51 According to some estimates, Slovakia has the second largest water resources in the world after neighbouring Austria; Aktuality (2016a) 4. Aktuality (2016a) <http://www.aktuality.sk/clanok/ 203502/slovensko-je-druhou-krajinou-na-svete-s-najvacsou-zasobou-pitnej-vody/> accessed 27 May 2016.

52 Further legal analyses of the amendment is discussed in Král (2016) 137-46.

53 Vláda SR (2016) Vláda SR (2016) <http://www.rokovania.sk/File.aspx/ViewDocumentHtml/ Uznesenie-12929? prefixFile $=u_{-}>$accessed 27 May 2016.

${ }^{54}$ For partial critique of this approach see Lalík (2013) 783-815. 


\section{Limitation on Personal Liberty}

The last analysed constitutional change was officially caused by the terrorist attacks in Paris that took place in November 2015. The result was an adoption of the constitutional statute No. 427/2015 Coll. of Laws from 8 December 2015 taking effect on January 1, 2016. ${ }^{55}$ This statute has supplemented Article $17 \S 3$ that protects the right to personal liberty. In respect of terrorist acts, the amendment has extended the time-limit for a person to be brought before a judge from 48 hours to 96 hours or be released. ${ }^{56}$

As with many other constitutional statutes, politics remained victorious over rationality and law. Slovakia is not under direct threat of a terrorist attack like other major European states. It is important to note that the terrorist legislation has been used only once in real criminal cases since its introduction in 2001. This was a case involving a psychopathic and mentally ill person (and animal lover), who constructed a bomb and put it into a basket in front of a McDonald's restaurant in Košice. No one was hurt during this incident and a person was accused but has not yet been sentenced for a terrorist act. This constitutional amendment, once more, was for rather populist purposes to demonstrate voters that they are protected from terrorists even at the constitutional level.

From a practical point of view and doing justice to international obligations of Slovakia, it is still necessary to interpret this provision in accordance with the Article $5 \S 3$ of the Convention. It provides that everyone arrested should be promptly brought before a judge. The notion of promptness for conventional purposes is assessed taking into account relevant circumstances of a given case while the ECtHR had refused to adopt wide interpretation of the term. Article $5 \S 3$ "leaves little flexibility in interpretation, otherwise there would be a serious weakening of a procedural guarantee to the detriment of the individual and the risk of impairing the very essence of the right protected by this provision." ${ }^{, 57}$ This approach is also applicable in the context of terrorism. ${ }^{58}$

\section{CONCLUSIONS}

The analyses shows that a vast range of issues have been covered by amendments in both objects of constitutional law; separation of powers and human rights law. In my view, at least three things especially in terms of rigidity of the Constitution and nature of changes can be stressed. The text has experienced 6 changes in the last 7 years. The Constitution is subject to change almost once a year (1.2 to be precise). This fact is definitely not an evidence of its rigidity but rather of its flexibility. A constitutional amendment is always an option for the National Council because gathering $90 \mathrm{MP}$ is not a serious problems as showed in practice. Constitutional change represents a very attractive possibility for minor and insignificant groups of MPs or even individual MPs to have their mark on the

55 Besides the constitutional statute in question, the National Council has amended many other statutes including Code of Criminal Procedure and Statute on Police Forces to strengthen the powers of police and further limit fundamental rights of persons accused of terrorist acts.

56 Originally, the bill contained even longer time-limit set out for 144 hours but such excessive time-limit was fortunately changed in the legislative process.

57 See among many authorities Kandzov v Bulgaria App. No. 68294/01 (ECtHR, 6 November 2008) $§ \S 65-66$.

58 See Brogan and Others $v$ UK App. No. 11209/84 (ECtHR, 29 November 1988), § 62. 
fundamental law of the Nation. ${ }^{59}$ On the other hand, the allocation of forces in the National Council does not (at least for now) allow for a single party to amend the Constitution unilaterally. And this brings us to the second feature.

Constitutional amendments remains fully in the realm of politics and politicians. They control the process of change from its beginning to the very end including its timing. Constitutional amendments that considerably alter the system and structure of the Constitution (as with constitutional laws No. 356/2011 or No. 161/2014) can be passed within a few hours or even overnight. Involvement of the Constitutional Court or other mechanisms to make process more complicated or slow it down are put on hold for now. A constitutional amendment that would change the whole process of constitutional change itself is not on the horizon because MPs would eventually lose their exclusivity over the process. ${ }^{60}$ Perhaps the interference of the Constitutional Court seems a possibility, but no one knows what would happen with a decision declaring a constitutional amendment unconstitutional because the Slovak institutions have had a decent record of not respecting its judgments in less important issues. ${ }^{61}$ The court is currently 3 judges short (10 out of 13 ) because the President refused to nominate candidates put forward by the National Council. ${ }^{62}$ The Constitutional Court is rather passive towards other branches of government as it does not use its power to declare statue unconstitutional very often. Average is lower than four cases a year. ${ }^{63}$

What is more pessimistic is the nature and context of constitutional amendments of a studied period. In general they represent accidental political compromises. Their content raises questions of conformity with the Constitution what even more undermines the unity of the document and damages constitutional culture among politicians and citizens. Ineffectiveness and unsystematic nature are major elements of amendments and the practice that surrounds them. Moreover, the majority of amendments were realized shortly before the general elections. They can be dubbed as lois spectacles in the full sense when the main

59 An extreme example can be the second sentence of Article $4 \S 1$ of the Constitution inserted by the constitutional statute No. 306/2014 Coll. of Laws that was proposed by the single MP (L'udovít Kaník).

${ }^{60}$ It remains questionable whether other mechanisms are useful and effective in practice. E.g. in Greece under Article 110 of the Greek constitution constitutional revisions take place in two parliamentary phases, between which general elections are held. However, this intended involvement of the people bears little influence on amendments in practice because Greeks due to polarisation in society tend to vote for their party at elections irrespective of an amendment in question. See Contiades and Fotiadou (2016) 200-201.

${ }^{61}$ E.g. decision not to adopt any constitutional statutes as only those envisaged by the Constitution itself (PL. ÚS 16/95); decision that abolished Specialised Court (PL. ÚS 17/08) when quite similar court is still a part of the judiciary; the obligation of the president to appoint nominations for constitutional court judges (PL. ÚS 45/2015 and III. ÚS 571/2014) what was not respected by the president and the Court is 3 judges short; decision abolishing a committee of the National Council that reviews decision of the National Security Office (PL. USS 6/04), the National Council adopted the same regulation as a constitutional statute in order to escape judicial review of such regulation etc.

${ }^{62}$ For further details see Lalík, Tomáš (2016) 'Constitutional Court Crisis in Slovakia: Still Far Away from Resolution', Blog of the International Journal of Constitutional Law and Constitution Making.org <http://www.iconnectblog.com/2016/08/constitutional-court-crisis-in-slovakia-still-faraway-from-resolution/> accessed 23 November 2016

${ }^{63}$ See Lalík (2015) 207. 
aim of the regulation is insignificant and what matters most is the propaganda and a gain in popularity. ${ }^{64}$ The moment of enactment demonstrates the nature of constitutional change to raise popularity among voters regardless of the damage caused to the a constitutional system. The constitutional changes have become a show-off political document.

I do not want to end up being pessimistic. This is the political constitutionalism in practice and its various proponents ranging from Richard Bellamy and Grégoire Webber to Jeremy Waldron or Mark Tushnet would be in the constitutional paradise. But would they?

\section{LITERATURE}

Albert, Richard, 'Constitutional Handcuffs' (2010) 42 Ariz. St. LJ 663-715.

Balog, Boris, Materiálne jadro Ústavy Slovenskej republiky (The Substantive Core of the Constitution of the Slovak Republic) (Eurokódex 2014).

Balog, Boris, 'Ústavné zákony v právnom poriadku Slovenskej republiky' (Constitutional Statutes in the Legal Order of the Slovak Republic) (2007) 59 Justičná revue 1575-84.

Balog, Boris Svák, Ján, 'Právo a politika alebo štvorhodinové blúdenie po slovenskej ústave' (Law and Politics or Four Hours of Straying in the Slovak Constitution) in Jirásek, Jiří (ed), Ústava ve stínu politiky? (Iuridicum Olomoucense 2012) 23-40.

Barak, Aharon, 'Unconstitutional constitutional amendments' (2011) 44 Isr L Rev 321-37.

Bernal, Carlos, 'Informal Constitutional Change: A Critical Introduction and Appraisal' (2014) 62 Am J Comp Law 493-514.

Breichová-Lapčáková, Marta, 'Neústavné ústavné zákony. II. čast”' (Unconstitutional Constitutional Statutes. 2 nd Part ) (2011) 63 Justičná revue 181-192.

Breichová-Lapčáková, Marta, Ústava a ústavné zákony (The Constitution and Constitutional Statutes) (Kalligram 2013).

Bröstl, Alexander, 'O ústavnosti ústavných zákonov' (On Constitutionality of Constitutional Statutes) in Masopust, Zdeněk and Jermanová, Hana (eds), Metamorfózy práva ve středni Evropě (Ústav státu a práva 2008) 11-26.

Contiades, Xenofon and Fotiadou, Alkmene, 'The Determinants of Constitutional Amendability: Amendment models or amendment culture?' (2016) 12 EuConst 192-211.

Drgonec, Ján, 'Zmena Ústavy Slovenskej republiky a otázky otvorené pre budúcu úpravu' (The Change of the Constitution of the Slovak Republic and Opened Questions for the Future Regulation) (2002) 54 Justičná revue 859-74.

Drgonec, Ján, Ústava Slovenskej republiky. Komentár (Constitution of the Slovak Republic. Commentary) (Heuréka 2012).

Drgonec, Ján, Ústava Slovenskej republiky. Teória a prax (Constitution of the Slovak Republic. Theory and Practice) (C.H. Beck 2015).

Elkins, Zachary, Ginsberg Tom and Melton, James, The Endurance of National Constitutions (CUP 2009).

Giba, Marián, 'Aktuálne nedostatky del'by a zodpovednosti moci v slovenskom ústavnom systéme (s dôrazom na postavenie prezidenta republiky a vlády)' (The Current Defects in the Separation of Powers and their Accountability in the Slovak Constitutional System (with the special accent on the Position of the President and the Government) in Klíma, Karel (ed), Odpovédnost veřejné moci. (Metropolitan University Prague Press 2013) 156-79.

Hartwig, Mathias, 'Much Ado About Human Rights: The Federal Constitutional Court Confronts the European Court of Human Rights - Part II/II' (2005) 6 GLJ 869-94.

Herc, Tomáš, 'Polemika o ústavnom poriadku a jeho kompatibilite' (Controversy about the Constitutional Order and Its Compatibility) (2009) 99 Právny obzor 410-26.

Král, Richard, 'Ústavný zákaz vývozu vody cez hranice Slovenskej republiky' (The Constitutional Prohibition on the Water Export outside the Slovak Republic) (2016) 68 Justičná revue 137-46.

${ }^{64}$ See also in case of Poland Łętowska (2014) 8. 
Lipšic, Daniel, 'K rozhodnutiu Ústavného súdu Slovenskej republiky o zmene ústavy referendom alebo Quis custodem custodiet?' (On the Decision of the Slovak Constitutional Court on the Constitutional Amendment by Referendum or Quis Custodem Custodiet?) (1997) 49 Justičná revue 21-33.

Łętowska, Ewa, "Prawo w “płynnej nowoczesności”" (Law in the Fluid Era) (2014) Państwo i Prawo $6-27$.

Lalík, Tomáš, 'Ústavnoprávna povaha Európskej únie' (The Constitutional Nature of the EU) (2013) 65 Justičná revue 783-815.

Lalík, Tomáš, Ústavný súd a parlament v konštitučnej demokracii (Constitutional Court and Parliament in the Constitutional Democracy) (Wolters Kluwer 2015).

Möllers, Christoph, 'Pouvoir constituant - Constitution - Constitutionalisation' in von Bogdandy, Armin, Bast, Jürgen (eds.) The Principles of European Constitutional Law (Hart Publishing 2006) 169-204.

Orosz, Ladislav, 'K problémom kompatibility ústavného systému Slovenskej republiky' (On the Problems of Compatibility of the Constitutional System of the Slovak Republic) (2005) 57 Justičná revue 323-41.

Procházka, Radoslav, Lud a sudcovia v konštitučnej demokracii ([The People and Judges in the Constitutional Democracy) (Aleš Čeněk 2011).

Prusák, Jozef, 'Zákon a konštitucionalizmus' (Statute and Constitutionalism) in Gerloch, Aleš and Maršálek, Pavel (eds), Zákon v kontinentálním právu (Eurolex 2005) 133-44.

Rousseau, Jean-Jacques, The Social Contract (Charles Frankel tr, Hafner Press 1947).

Schmitt, Carl, Constitutional Theory (Jeffrey Seitzer tr, Duke University Press 2008).

Zelenajová, Zuzana, 'Inštitút referenda v SR - aktuálne otázky' (The Institute of Referendum in the SR - Current Issues) in Milniky práva v stredoeurópskom priestore (Univerzita Komenského Právnická fakulta 2015) 599-604.

Zupančič, Boštjan, The Owl of Minerva. Essays on Human Rights (Eleven International Publishing 2008). 